\title{
DAMPAK KURANGNYA PERHATIAN ORANG TUA TERHADAP PERKEMBANGAN KARAKTER ANAK
}

\author{
Oleh : Suriati ${ }^{1}$
}

$* * * *$

\begin{abstract}
Abstrak
Perhatian orang tua terhadap perkembangan karakter anak sangat penting, artinya pengembangan karakter hanya dapat dilakukan dalam suatu proses perhatian khusus orang tua dan tidak melepaskan anak sepenuhnya dibentuk oleh lingkungan sekolah, sosial, dan budaya masyarakat yang terkadan tidak sehat. Keluarga merupakan institusi pendidikan utama dan pertama bagi anak. Karena anak untuk pertama kalinya mengenal pendidikan didalam lingkungan keluarga sebelum mengenal masyarakat yang lebih luas. Disamping itu keluarga dikatakan sebagai peletak pondasi untuk pendidikan selanjutnya.
\end{abstract}

\section{Kata Kunci : Perhatian,Pola Asuh,Karakter Anak}

\section{PENDAHULUAN}

\section{A. Latar Belakang Masalah}

Anak merupakan amanah Allah SWT yang harus dijaga dan dibina, hatinya yang suci adalah permata yang sangat mahal harganya. Jika dibiasakan pada kejahatan dan dibiarkan seperti dibiarkannya binatang, maka ia akan terbiasa dengan hal-hal yang jahat pula. Anak sejak dilahirkan telah membawa fitra keagamaan. Fitra itu baru berfungsi dikemudian hari melalui proses bimbingan dan latihan setelah berada pada tahap kematangan. ${ }^{2}$ Seoarng anak yang tidak

\footnotetext{
${ }^{1}$ Dosen STAIN Palu.

2 Jalaluddin, Psikologi Agama: Memahami prilaku keagamaan dengan mengaplikasikan prinsip-prinsip psikologi, (Edisi Revisi; Jakarta: PT. Raja Grafindo Persada, 2010), h. 65.
} 
terurus oleh orang tuanya maka akan dibentuk oleh lingkungan pergaulan yang tidak sehat, oleh karena itu orang tualah yang memegang faktor kunci yang bisa menjadikan anak tumbuh dengan jiwa Islami melalui pendidikan dan mengajarinya akhlak yang baik.

Orang tua hendaknya selalu menanamkan keyakinan yang kuat kepada anak-anaknya yakni dengan menjadikan anak selalu merasa bahwa Allah mendengar bisikan dan pembicaraannya, melihat setiap gerak-geriknya serta mengetahui apa yang dirahasiakan dan disembunyikan. Karakter seperti inilah yang harus menghiasi kehidupan anak sehingga selalu termotivasi untuk berbuat baik dan menjauhi segala keburukan yang tidak sesuai dengan norma agama. Karakter dan SQ adalah hal yang berbeda tapi memiliki kesamaan yang merupakan landasan untuk memfungsikan IQ dan EQ secara efektif.

Karakter adalah watak, tabiat, akhlak, atau kepribadian seseorang yang terbentuk dari hasil internalisasi berbagai kebajikan (virtues) yang diyakini dan digunakan sebagai landasan untuk cara pandang, berpikir, bersikap, dan bertindak. ${ }^{3}$ Kecerdasan spiritual adalah kemampuan untuk memberi makna ibadah terhadap setiap perilaku dan kegiatan, melalui langkah-langkah dan pemikiran yang bersifat fitrah menuju manusia yang seutuhnya (hanif) dan memiliki pola pemikiran tauhid (integralistik), serta berprinsip "hanya karena Allah". 4

Islam mengupayakan pembinaan seluruh potensi manusia secara serasi dan seimbang dengan terbinanya seluruh potensi manusia secara sempurna diharapkan ia dapat melaksanakan fungsi pengabdiannya sebagai khalifah di muka bumi. Untuk dapat melaksanakan pengabdian tersebut harus dibina seluruh potensi yang dimiliki yaitu potensi spiritual, kecerdasan, perasaan

\footnotetext{
3 Kementerian Pendidikan Nasional Badan Penelitian dan Pengembangan Pusat Kurikulum, Pengembangan pendidikan budaya dan karakter bangsa, (Cet. I; Jakarta: 2010), h. 3.

4 Ary Ginanjar Agustian, Rahasia Sukses Membangun Kecerdasan Emosi dan Spiritual ESQ (Cet. I; Jakart: Penerbit Arga, 2001), h. 57.
} 
dan kepekaan. Potensi-potensi itu sesungguhnya merupakan kekayaan dalam diri manusia yang amat berharga. ${ }^{5}$ Pembinaan dan bimbingan potensi-potesi tersebut kepada anak merupakan kewajiban orang tua.

Ketiadaan kecerdasan ruh akan mengakibatkan hilangnya ketenangan bathin dan pada akhirnya akan mengakibatkan hilangnya kebahagiaan pada diri orang tersebut. Besarnya kecerdasan ruh lebih besar dari pada kecerdasan hati dan kecerdasan otak atau kecerdasan ruh cendrung meliputi kecerdasan hati dan kecerdasan otak. ${ }^{6}$

Peranan orang tua sangat berpengaruh sekali dalam mendidik anak-anaknya terutama sekali di dalam pendidikan agama Islam. Anak merupakan bahagian dari masyarakat yang dipundaknya terpikul beban pembangunan dimasa mendatang, dan juga sebagai generasi penerus dari yang tua-tua, maka dari itu orang tua harus lebih memperhatikan, selalu membimbing, dan mendidik dengan baik sehingga tercapailah baginya kebahagiaan dunia dan kebahagiaan akhirat.

Dalam lingkungan sosial anak-anak akan menghadapi berbagai macam kesulitan dan ketidak stabilan sosial. Jelas, mereka akan menghadapi berbagai macam karakter manusia dengan adat istiadatnya yang berbeda-beda, bahkan mereka akan juga menghadapi berbagai macam penyimpangan perilaku. Oleh karenanya untuk menjaga mereka dari berbagai penyimpangan, mereka memerlukan pengawasan dan perhatian khusus, dan ini adalah tugas kedua orang tua yang harus menyiapkan fondasinya. ${ }^{7}$

Ironisnya karena sebahagian orang tua mengabaikan kewajibannya sebagai pendidik pertama dalam kehidupan anak, malah terkadang orang tua mendidik dengan prilaku shaming, yaitu prilaku yang bisa mempermalukan, mencela, menghardik, dan tindakan verbal yang kasar

\footnotetext{
${ }^{5}$ Abuddin Nata, Filsafat Pendidikan Islam. (Cet. I; Jakarta: Logos Wacana Ilmu, 1997), h. 51.

${ }^{6}$ Dedhi Suharto, et.al, Qur'anis Quotient, (Cet. I; Jakarta: Yayasan Ukhuwah, 2003), h. 53.

${ }^{7}$ Mahalena Ristriyantih, Pengaruh kesalahan orang tua mendidik anak terhadap perkembangan perilaku anak, (Semarang: Universitas Islam Sultan Agung, 2011), h. 3.
} 
lainnya terhadap anak. Bila anak kurang perhatian dan terbiasa dengan atau label negatif yang didengar dari orang di sekitanya untuk dirinya, maka secara berangsur label itu akan mengendap di bawah alam sadarnya. Dan pengaruhnya amat sangat besar, ia bisa men-cap dirinya memiliki karekter nakal, atau cengeng, atau karakter negatif lainnya.

Untuk mengantisipasi hal ini, maka Allah mengingatkan kepada orang tua agar mempertahankan keturunannya. QS. An-Nisa (4): 9

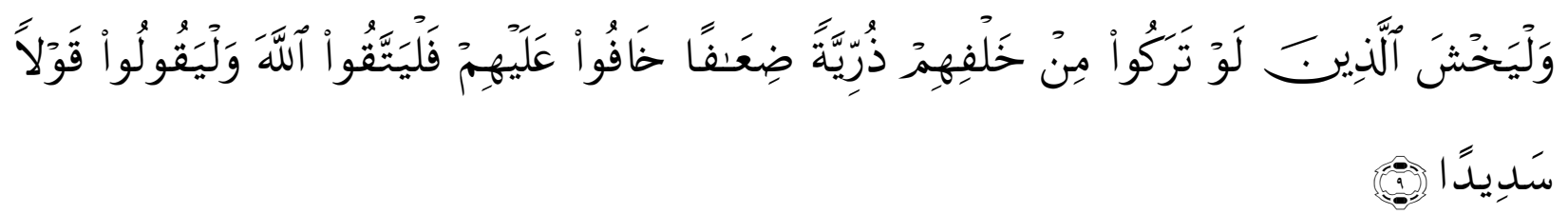

Terjemahan:

Dan hendaklah takut kepada Allah orang-orang yang seandainya meninggalkan dibelakang mereka anak-anak yang lemah, yang mereka khawatir terhadap (kesejahteraan) mereka. oleh sebab itu hendaklah mereka bertakwa kepada Allah dan hendaklah mereka mengucapkan Perkataan yang benar. ${ }^{8}$

Ayat di atas mengisyaratkan kepada orang tua agar tidak meninggalkan anak mereka dalam keadaan lemah. Lemah maksudnya adalah lemah dalam segala aspek kehidupan seperti lemah mental, psikis, pendidikan, ekonomi terutama lemah iman (spiritual). Anak yang lemah iman akan menjadi generasi tanpa kepribadian. Jadi semua orang tua harus memperhatikan semua aspek perkembangan anaknya baik itu dari segi perhatian, kasih sayang, pendidikan mental, maupun masalah aqidah atau keimanannya.

Karakter anak dikemudian hari ditentukan bagaimana cara-cara orang tua mendidik dan membesarkannya. Beranjak dari apa yang penulis paparkan di atas maka ditarik kesimpulan sementara bahwa kurangnnya perhatian orang tua kepada anak berdampak pada perkembangan karakter anak.

8 Departemen Agama RI, Al-Qur'an dan Terjemahannya, (Ed. Khat Madinah; Bandung: Syamil Cipta Media, 2005), h. 78. 


\section{Rumusan Masalah dan Batasan Masalah}

\section{Rumusan Masalah}

Rumusan masalah dimaksudkan sebagai penegasan atas masalah pokok yang akan dikaji, diformulasikan dalam bentuk pertanyaan penelitian (research question). Adapun rumusan masalah dalam skripsi ini adalah:

a. Bagaimana keterkaitan antara kurangnya perhatian orang tua terhadap perkembangan karakter anak?

b. Bagaimana dampak kurangnya perhatian orang tua terhadap perkembangan karakter?

\section{PEMBAHASAN}

\section{A. Perhatian Orang Tua}

Orang tua merupakan pembentuk kepribadian anak yang pertama kali, karena orang tua merupakan teladan bagi anak-anaknya. Menurut Zakiyah Darajat kepribadian orang tua, sikap, dan cara hidup merupakan unsur-unsur pendidikan yang secara tidak langsung akan masuk kedalam pribadi anak mereka yang sedan tumbuh. ${ }^{9}$ Interaksi seseorang anak dengan orang tua dipastikan dapat menumbuhkan karakter anak. Oleh karena itu, perhatian orang tua yang utama adalah pengembangan karakter individu orang tua itu sendiri.

Pendidikan yang diterima anak dalam keluarga inilah yang akan digunakan oleh anak sebagai dasar untuk mengikuti pendidikan selanjutnya disekolah. Orang tua sebagai pendidik pertama dan utama bagi anak merupakan penanggung jawab penuh terhadap karakter anakanaknya. Tugas dan tanggung jawab orang tua dalam keluarga terhadap karakter anak-anaknya lebih bersifat pembentukan watak, agama dan spiritualnya.

\footnotetext{
${ }^{9}$ Zakiayah Darajat, Ilmu Jiwa Agama, (Jakarta: Bulan Bintang, 1996), h. 63.
} 
Secara psikososiologi keluarga berfungsi sebagai:

1. Pemberi rasa aman bagi anak dan anggota keluarga lainya.

2. Memberi pemenuhan kebutuhan baik fisik maupun psikis.

3. Sumber kasih sayang dan penerimaan.

4. Model pola perilaku yang tepat bagi anak untuk belajar menjadi anggota masyarakat yang baik.

5. Pemberi bimbingan bagi pengembangan perilaku yang secara sosial dianggap tepat.

6. Pembentuk anak dalam memecahkan masalah yang yang dibutuhkan untuk penyesuaian diri.

7. Pemberi bimbingan dalam belajar keterampilan motorik, verbal dan sosial yang dibutuhkan untuk penyesuaian diri

8. Stimulator bagi pengembangan kemampuan anak untuk mencapai prestasi, baik disekolah maupun dimasyarakat.

9. Pembimbing dalam mengembangkan aspirasi, dan

10. Sumber persahabatan atau teman bermain bagi anak sampai cukup usia untuk mendapatkankan teman diluar rumah, atau apabila persahabatan diluar rumah tidak memungkinkan. ${ }^{10}$

Anak yang berkarakter tidak hanya memiliki hubungan yang baik dengan sesamanya tetapi juga memiliki hubungan yang kuat dengan Allah, sehingga akan berdampak pula kepada kepandaian dia dalam berinteraksi dengan manusia, karena dibantu oleh Allah yaitu hati manusia

10 Syamsu Yusuf LN, Psikologi Perkembangan Anak dan Remaja, (Cet. II; Bandung: Rosda Karya, 2001), h. 38 
dijadikan cendrung kepada-Nya. ${ }^{11}$ Sedangkan dari sudut pandang sosiologis, fungsi keluarga dapat diklasifikasikan kedalam fungsi-fungsi berikut:

1. Fungsi biologis,

2. Fungsi ekonomis

3. Fungsi pendidikan (edukatif)

4. Fungsi sosialisasi

5. Fungsi perlindungan (protektif)

6. Fungsi rekreatif

7. Fungsi agama (religius). ${ }^{12}$

Untuk lebih jelasnya akan penulis kemukakan satu persatu antara lain :

1. Fungsi biologis, artinya keluarga merupakan tempat memenuhi semua kebutuhan biologis keluarga seperti; sandang, pangan dan sebagainya.

2. Fungsi ekonomis, maksudnya dikeluargalah tempat orang tua khususnya ayah untuk memenuhi semua kewajibanya selaku kepala keluarga.

Fungsi ekonomi dijelaskan dalam QS. Al-Baqarah (2): 233.

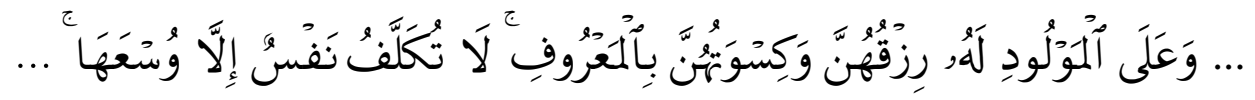

Terjemahan:

... dan kewajiban ayah memberi makan dan pakaian kepada para ibu dengan cara ma'ruf. seseorang tidak dibebani melainkan menurut kadar kesanggupannya ...

11 Mas Udik Abdullah, Meledakkan IESQ dengan Langkah Taqwa dan Tawakal, (Cet. I: Jakarta: Zikrul Hakim, 2005), h. 181.

${ }^{12}$ Ibid, h. 39.

13 Departemen Agama RI, Al-Qur'an dan Terjemahannya, edisi Khat Madinah. (Cet. II; Bandung: Syamil Cipta Media, 2005), h. 37. 
3. Fungsi pendidikan, dimana dikeluargalah tempat dimulainya pendidikan semua anggota keluarga.

4. Fungsi sosisalisasi, maksudnya keluarga merupakan buaian atau penyemaian bagi masyarakat masa depan.

5. Fungsi perlindungan, keluarga merupakan tempat perlindungan semua keluarga dari semua gangguan dan ancaman.

6. Fungsi rekreatif, keluarga merupakan pusat dari kenyamanan dan hiburan bagi semua anggota keluarganya.

7. Fungsi agama, maksudnya keluarga merupakan tempat penanaman agama bagi keluarga.

Kebiasaan orang-orang disekitar anak akan ikut mewarnai karakter anak, oleh karena itu Islam melarang bergaul dengan teman yang jahat dan buruk. Pertumbuhan anak dibawah asuhan ayah dan ibu merupakan sebaik-baik sarana bagi pembinaan karakternya. Namun demikian, kurangnya pengetahuan anggota keluarga juga dapat berpengaruh (negatif) bagi keturunan mereka. Perhatian keluarga dipandang sebagai pendidikan pertama dan utama karena peranannya yang begitu besar sebagai peletak pondasi pengembangan-pengembangan berikutnya. Pembinaan karakter yang diberikan orang tua terhadap anak mempunyai peran yang besar sekali bagi kehidupan dan masa depan anak, karena pada dasarnya perhatian terhadap karakter anak merupakan upaya untuk memanusiakan manusia.

Pembinaan karakter anak merupakan upaya pengembangan potensi fitra yang dibawa anak sejak lahir yakni potensi untuk beragama. Peranan ibu dalam pendidikan anak lebih dominan dari peranan ayah, hal ini agaknya dapat dipahami karena ibulah orang yang lebih 
banyak mengerti anak sejak seorang anak lahir, ibulah orang yang selalu ada di sampingnya, bahkan dikatakan bahwa pengaruh ibu terhadap anaknya dimulai sejak dalam kandungan. ${ }^{14}$

Peranan ayah terhadap anaknya tidak kalah pentingnya dari peranan ibu. Ayah merupakan sumber kekuasaan yang memberikan anaknya tentang manajemen dan kepemimpinan, sebagai penghubung antara keluarga dan masyarakat dengan memberikan perhatian terhadap anaknya berupa komunikasi terhadap sesamanya memberi perasaan aman dan perlindungan terhadap keluarganya. ${ }^{15}$ Secara garis besar ada dua kebutuhan anak yakni kebutuhan jasmani dan kebutuhan rohani/pembinaan karakter (spiritual). Kebutuhan jasmani anak seperti makanan, pakaian, perumahan, kesehatan dan sebagainya.

Antara kebutuhan jasmani dan rohani/pembinaan karakter (spiritual) terdapat keterkaitan satu sama lain. Dari satu sisi, dalam kedokteran dikatakan bahwa kualitas makanan yang diberikan kapada anak balita akan menentukan kualitas kecerdasan dan kemampuan anak. Upaya pencerdasan dapat dilakukan oleh siapa saja tidak memandang apakah ibu yang hamil itu cerdas atau tidak. Sepertinya kepribadian dan kecerdasan anak terbangun melalui transmisi spiritual, intelektual, emosional dan moral ibunya.

Karena itu ibu yang sedang hamil sangat dianjurkan untuk meningkatkan bobot spiritual, emosional, moral dan intelektualitasnya. Peningkatan ini banyak ditempuh dengan memperbanyak ibadah shalat sunat, membaca dan mentala'ah Al-Quran, menjaga tutur kata, gemar berinfak dan bersedekah (dermawan) serta akhlak terpuji lainya. ${ }^{16}$ Berdasarkan hal tersebut, orang tua (ayah dan ibu) hendaknya memperhatikan keseimbangan antara kebutuhan jasmani dan rohani/pembinaan karakter (spiritual) anak. Oleh sebab itu orang tua harus

\footnotetext{
${ }^{14}$ Abu Ahmadi, Ilmu Pendidikan, (Semarang: CV. Toha Putra, 1987), h. 180.

15 Rehani, Keluarga Sebagai Institusi Pendidikan dalam Perspektif Al-Qur'an, (Cet. I; Yogyakarta: Baitul hikmah Press, 2001), h. 91.

${ }^{16}$ Suharsono, Mencerdaskan Anak, (Cet. III; Jakarta: Intiusi Press, 2000), h. 118.
} 
memberikan makanan yang halal dan bergizi kepada anak balita agar otaknya tumbuh dengan sempurna, disamping melakukan anak dengan penuh kasih sayang.

Faktor kasih sayang juga sangat menentukan perkembangan karakter anak. Namun dewasa ini tidak sedikit para orang tua yang kurang memperhatikan keseimbangan antara kebutuhan jasmani dan kebutuhan rohani/pembinaan karakter anak. Orang tua cendrung lebih memperhatikan kebutuhan jasmani anak dari pada kebutuhan rohani/pembinaan karakter. Hal ini dapat dilihat dari kenyataan bahwa semakin banyaknya anak-anak yang sehat dan cerdas tetapi karakternya jauh dari harapan.

Sebagai contoh, Irianti Erning Praja (28 th) seorang presenter dan pencipta lagu. Ia belum merasakan kepuasan, Irianti memang bangga akan semua prestasi yang diraihnya, namun dia masih merasa kosong seolah-olah tidak ada sesuatu yanag besar telah terjadi, prestasinya juga tercetak di dunia olah raga. Berulang kali dia memperoleh mendali di tingkat Internasional, di tingkat SEA Games, ditingkat ASIA Games. Irianti juga pernah menyabet mendali emas untuk renang tahun 1977, namun segudang prestasi ini hanya berlalu begitu saja di hatinya. Dibidang akademis, Irianti juga pernah mendapatkan beasiswa dan dia juga tercatat sebagai alumni Jurusan Statistik Institut Pertanian Bogor.

Selain itu ia juga merasa dirinya cepat sekali marah, ada orang salah sedikit kepadanya dia pasti marah, bahkan Irianti sempat mengubah namanya karena kesal banyak orang salah menulis namanya. Kegelisahan Irianti mulai reda setelah ia membaca buku-buku tentang pengembangan diri terutama masalah kecerdasan spiritual dan karakter. Dia mulai menyadari walaupun dia punya segudang kecerdasan, tetapi jika tidak dibarengi dengan karakter yang baik, 
jiwanya tidak akan merasakan kebahagiaan. Irianti merupakan salah seorang contoh dari ribuan, bahkan jutaan anak yang tidak merasakan kebahagiaan atas apa yang telah mereka raih. ${ }^{17}$

Disinilah barang kali letak kesenjangan perhatian sebagai orang tua dalam kaitannya dengan karakter anak. Karena itulah setiap orang tua harus menyadari dan memperhatikan keseimbangan antara kebutuhan jasmani dan pembinaan karakter anaknya.

Berdasarkan contoh diatas menunjukkan betapa pentingnya membina karakter anak, khususnya dalam lingkungan keluarga. Penulis mengajak kepada para orang tua supaya lebih memperhatikan anak-anaknya, tidak hanya dari segi jasmani dan IQnya saja, tetapi juga memperhatikan bahkan harus lebih mengutamakan pembinaan karakternya. Pendidikan karakter termasuk bidang-bidang pendidikan yang harus mendapat perhatian penuh oleh keluarga (orang tua) terhadap anak-anaknya. Pendidikan karakter berarti membangkitkan kekuatan dan perkembangan spritual yang bersifat naluri pada anak melalui bimbingan agama yang sehat dan mengamalkan ajaran-ajaran agama.

Begitu juga dengan mengajarkan kepadanya cara-cara yang betul untuk menunaikan syiar-syiar dan kewajiban agama, dan menolong mengembangkan sikap agama yang betul, termasuk mula-mula sekali adalah iman yang kuat kepada Allah, malaikat, kitab-kitab-Nya, rasul-rasul-Nya, hari akhirat, takut kepada Allah dan selalu merasa mendapat pengawasan dari Allah dalam segala perbuatan dan perkataan. ${ }^{18}$ Sebagaimana penulis ketahui bahwa keluarga adalah sebagai persekutuan hidup terkecil dari masyarakat negara yang luas, pangkal ketentraman dan kedamaian kehidupan adalah terletak dalam keluarga.

\footnotetext{
${ }^{17}$ Dikutip dari Hendra Susanti, Peranan orang tua dalam membina kecerdasan spiritual anak dalam keluarga, (Padang: STAI Pengembangan Ilmu Al-Qur'an Sumatera Barat, 2006), h. 48.

${ }^{18}$ Hasan Langgulung, Manusia dan Pendidikan Suatu Analisa Psikologi dan Pendidikan, (Cet. III; Jakarta: PT. Al Husna Zikra, 1995), h. 372.
} 
Mengingat betapa pentingnya hidup keluarga yang demikian itu, maka Islam memandang keluarga bukan hanya sebagai persekutuan hidup terkecil saja, tetapi lebih dari itu yakni sebagai lembaga hidup manusia yang dapat memberi kemungkinan celaka dan bahagianya anggota-anggota keluarga tersebut dunia dan akhirat. ${ }^{19}$

Dengan demikian keluarga mempunyai kewajiban yang tidak kecil, karena baik buruk atau sukses tidaknya anggota keluarga merupakan tanggung jawabnya. Dalam hal ini orang tua sebagai kepala keluarga memang dituntut untuk mewarnai keluarga dengan nilai dan akhlak yang baik, suri tauladan yang baik (karakter) sehingga dapat menyelamatkan aggota keluarga dari segala bentuk keresahan dan kesusahan, baik susahnya perjuangan dunia maupun akhirat. Keluarga merupakan "training centre" bagi penanaman nilai-nilai pengembangan fitrah atau jiwa beragama anak, seyogianya bersamaan dengan perkembangan kepribadianya yaitu sejak lahir bahkan lebih dari itu sejak dalam kandungan. ${ }^{20}$

Pandangan ini didasarkan pengamatan para ahli jiwa terhadap orang-orang yang mengalami gangguan jiwa, ternyata dipengaruhi oleh keadaan emosi atau sikap orang tua (terutama ibu) pada waktu anak masih dalam kandungan. ${ }^{21}$ Oleh karena itu, sebaiknya pada saat bayi masih berada dalam kandungan, orang tua (terutama ibu) seyogianya lebih meningkatkan amal ibadahnya kepada Allah, seperti melaksanakan shalat wajib dan shalat sunat, berdo’a, berzikir, membaca Al-Qur'an dan memberi sedekah serta amalan shaleh lainnya.

19 An Nida', Pendidikan, Bahasa, dan Kepemudaan, Majalah Ilmu Pengetahuan Agama Islam, (Cet. XIX; Jakarta: Pusat Penelitian IAIN Sultan Syarif Qosim Pekan Baru, 1997), h. 21.

${ }^{20}$ Menurut Hurlock dikutip dari Hendra Susanti, Peranan orang tua dalam membina kecerdasan spiritual anak dalam keluarga, h. 56.

${ }^{21}$ Syamsu Yusuf LN, Psikologi Perkembangan Anak dan Remaja, h. 138 
Dalam membina dan mengembangkan karakter anak dalam lingkungan keluarga, disamping upaya-upaya yang telah dilakukan diatas, maka ada pula beberapa hal lain yang perlu menjadi perhatian orang tua yaitu sebagai berikut:

1. Karena orang tua merupakan pembina pribadi yang pertama bagi anak, dan tokoh yang diidentifikasi atau ditiru anak, maka seyogianya dia memiliki kepribadian yang baik atau berakhlakul karimah (akhlak yang mulia). Kepribadian orang tua, baik yang menyangkut sikap, kebiasaan berprilaku atau tata cara hidupnya merupakan unsur-unsur pandidikan yang tidak langsung memberikan pengaruh terhadap perkembangan fitrah beragama anak.

2. Orang tua hendaknya memperlakukan anaknya dengan baik. Perlakuan yang otoriter (perlakuan yang keras) akan mengakibatkan perkembangan pribadi anak yang kurang diharapkan, begitu pula perlakuan yang permisif (terlalu memberi kebebasan) akan mengembangkan pribadi anak yang tidak bertanggung jawab atau kurang memperdulikan tata nilai yang dijunjung tinggi dalam lingkungannya. Sikap dan perlakuan orang tua yang baik adalah yang mempunyai karakteristik:

a. Memberikan curahan kasih sayang yang ikhlas

b. Bersikap respek atau menghargai pribadi anak

c. Menerima anak sebagaimana biasanya

d. Mau mendengarkan pendapat atau keluhan anak

e. Memaafkan kesalahan anak, meminta maaf bila ternyata orang tua sendiri salah kepada anak

f. Meluruskan kesalahan anak dengan pertimbangan atau alasan-alasan yang tepat

3. Orang tua hendaknya memelihara hubungan yang harmonis antar anggota keluarga (ayah dengan ibu, orang tua dengan anak, dan anak dengan anak). Hubungan yang harmonis penuh 
pengertian dan kasih sayang akan membuahkan perkembangan perilaku anak yang baik. Sedangkan yang tidak harmonis, seperti sering terjadi pertentangan atau perselisihan akan mempengaruhi perkembangan pribadi anak yang tidak baik, seperti keras kepala, pembohong dan sebagainya.

4. Orang tua hendaknya membimbing, mengajarkan atau melatih ajaran agama terhadap anak seperti: Syahadat, Shalat (bacaan dan gerakanya), Do'a-do'a, Bacaan Al-Qur'an, lafaz zikir dan akhlak terpuji seperti bersyukur ketika mendapat anugerah, bersikap jujur menjalin persaudaraan dengan orang lain, dan menjauhkan diri dari perbuatan yang dilarang Allah. ${ }^{22}$

Untuk memelihara keluarga dari segenap hal-hal yang dapat menjerumuskan kedalam neraka tentu tidak mudah begitu saja. Karena itu dibutuhkan suatu proses pengertian dan pemahaman yang mendalam terhadap tugas-tugas tersebut. Sebagai orang tua, tidak hanya berkewajiban memenuhi kebutuhan jasmaniah anak semata tetapi juga kebutuhan akan spiritual anak dalam mencapai kebahagiaan dunia dan akhirat. Dengan cara membiasakan anak sejak dini dengan hal-hal yang sesuai dengan nilai-nilai kesusilaan dan agama diharapkan akan terbentuk karakter yang kuat, sehingga pada gilirannya anak dapat membedakan mana yang baik dan terbaik dan mana yang buruk dan terburuk, mana yang benar dan mana yang salah dalam kehidupan sehari-hari.

\section{B. Karakter Anak}

Dalam Kamus Besar Bahasa Indonesia, karakter bermakna aktor atau peran atau pemeran. ${ }^{23}$ Karakter adalah watak, tabiat, akhlak, atau kepribadian seseorang yang terbentuk dari hasil internalisasi berbagai kebajikan (virtues) yang diyakini dan digunakan sebagai

\footnotetext{
${ }^{22}$ Ibid, h. 139.

23 KBBI offline versi. 1.1, Kamus Besar Bahasa Indonesia. (Ed. III; Jakarta: http:// pusatbahasa.diknas.go.id/kbbi/, 2010)
} 
landasan untuk cara pandang, berpikir, bersikap, dan bertindak. ${ }^{24}$ Saat kita berada di kantor, di pasar, di jalanan dan dimanapun berada seringkali terdengar sebuah pertanyaan, "ini anak siapa ?". Maka seorang ibu atau bapak akan dengan sigap mengatakan, “itu anak saya”. Kemudian pada saat yang bersamaan orang yang bertanya memuji anak tersebut maka spontan senyum sang ayah atau ibu itu pun mengembang.

Kebanggaan sebagai orang tua tampak benar di raut wajahnya. Sebuah pertanyaan sederhana, siapakah sebenarnya yang membentuk karakter dan perilaku anak ? Apakah ayahnya, ibunya, campuran keduanya, pengasuhnya atau yang lainnya?

Ada beberapa hal yang bisa mempengaruhi terbentuknya karakter anak :

1. Anak sering menirukan orang yang paling sering berinteraksi dengannya. Bagi orang tua yang menginginkan anaknya berkarakter, maka ia harus sesering mungkin berinteraksi dan memperlihatkan tauladan yang baik kepada anak-anaknya.

2. Anak sering menirukan orang yang paling ia percaya. Orang tua harus mampu menjadi tauladan dan dipercaya anak. Jangan sekali kali membohongi mereka. Mungkin orang tua tidak sengaja berbohong, namun memori anak merekam janji orang tuanya dengan baik.

3. Anak sering menirukan orang yang mengajarkan sesuatu padanya untuk pertama kali dan atau berkesan. Sering-seringlah mengajarkan hal baru dan berkesan bagi anak, hal baru dan berkesan itu diharapkan menjadi kebiasaan baik (karekter) bagi anak. Sebagai contoh, mengajarkan anak makan dengan tangan kanan, membiasakan anak ikut serta dalam salat berjamaah, dll. Hal-hal buruk sangat mudah diperoleh dari lingkungan sekitar, jangan biarkan hal-hal buruk tersebut menjadi pertama kali, sering, dan berkesan dalam kehidupan anak.

24 Kementerian Pendidikan Nasional Badan Penelitian dan Pengembangan Pusat Kurikulum, Pengembangan pendidikan budaya dan karakter bangsa, (Cet.I; Jakarta: 2010), h. 3. 
4. Anak sering menirukan orang yang mengajarkan sesuatu dengan menyenangkan (menurut anak). Untuk itu kiranya orang tua harus mampu bertindak sebagai teman dan sahabat bagi anak-anaknya. Jika anak merasa orang tuanya menyenangkan, maka anak akan selalu merasa senang bila bersama orang tuannya, jadikan anak menyenangi hal-hal yang baik sebab bila tidak maka besar kemungkinan anak akan menjadikan hal-hal buruk sebagai kebiasaan. $^{25}$

Orang tua yang baik tentu saja akan melakukan segalanya demi anak. Termasuk pembentukan karakter tentunya. Jangan sampai kesempatan emas orang tua dalam membentuk karakter ini diambil alih oleh lingkungan yang tidak sehat. Memberi perhatian penuh kepada anak adalah hal wajib yang harus dilakukan orang tua, kapanpun dan dimanapun.

\section{Pembinaan Karakter Anak}

Untuk mengembangkan karakter anak maka orang tua atau guru harus menjadi gembala spiritual yang baik. ${ }^{26}$ Orang tua harus selalu megawasi keseharian anak, membimbing setiap saat dalam membiasakan hal-hal baik dan meluruskan/menegur bila terjadi kekeliruan dalam prilaku anak. Dalam mengembangkan karakter anak orang tua juga harus menjadi tauladan bagi anakanaknya, sehingga tidak mental ketika menegur atau memberi petunjuk kepada anak. Untuk mengembangkan pembinaan karakter anak khususnya pembinaan dalam keluarga, berikut ini beberapa tips yang dapat diperhatikan oleh orang tua:

1. Melalui "jalan tugas"

2. Melalui "jalan pengasuhan"

3. Melalui "jalan pengetahuan"

${ }^{25}$ Lambang Sarib, Empat hal yang mempengaruhi pembentukan karakter anak, artikel. Diakses 24 April 2014, dari http:// lambangsarib.wordpress.com, 27 Desember 2012.

${ }^{26}$ Henra Susanti, Peranan orang tua dalam membina kecerdasan spiritual anak dalam keluarga, Sripsi S1, (Padang: STAI Pengembangan Ilmu Al-Qur'an Sumatera Barat, 2006), h. 73. 
4. Melalui "jalan perubahan pribadi"

5. Melalui "jalan persaudaraan"

6. Melalui “jalan kepemimpinan yang penuh pengabdian". ${ }^{27}$

Untuk lebih jelasnya akan penulis uraikan satu persatu, yaitu :

\section{Melalui Jalan Tugas}

Yaitu anak dilatih melakukan tugas-tugas hariannya dengan dorongan motivasi dari dalam. Artinya anak melakukan setiap aktifitasnya dengan perasaan senang, bukan karena terpaksa atau karena paksaan orang tua. ${ }^{28}$ Biasanya anak akan melakukan tugas-tugasnya dengan penuh semangat apabila dia tau manfaat baginya. Untuk itu orang tua perlu memberi motivasi, membuka wawasan sehingga setiap tindakan anak-anak tersebut secara bertahap dimotivasi dari dalam.

Anak perlu diberi waktu menggunakan kebebasan pribadinya, membenamkan diri pada aktifivitas-aktivitas favoritnya seperti membaca, menatap tembok, mendengarkan musik, menari, memancing, dan sebagainya. Permainan-permainan ini membuat anak-anak produktif dan mengembangkan kekayaan kecerdasan dalam diri mereka. Didalam keluarga perlu kondisi yang mendukung pengembangan kondisi batin anak agar dapat berkhayal, berangan-angan, mengembangkan fantasinya, dan bermain.

Permainan membuka pintu bakat dan membuat orang bebas berpikir dan dengan demikian mengembangkan kecerdasan. Permainan memungkinkan anak-anak mengenal dirinya sendiri. Permainan adalah guru terbaik bagi anak-anak. Permainan membuka pintu untuk memasuki suatu yang mungkin dirasakan seseorang anak sebagai tatanan yang sudah ada

${ }^{27}$ Monty P. Satia Darma dan Fidelis E. Waruwu, Mendidik Kecerdasan, (Cet. 1; Jakarta: Pustaka Populer Obor, 2003), h. 48.

${ }^{28} \mathrm{Ibid}$. 
sebelumnya. Permainan membantu anak terhubung dengan bebas ke dunianya dan dengan mudah menghabiskan waktunya penuh kualitas.

Kebebasan berpikir yang efektif dan positif akan berkembang dalam diri anak yang merencanakan, memulai, dan menentukan sendiri arah permainannya. Berhubungan dengan hal itu, sifat-sifat orang tua yang sangat mengekang atau mengendalikan anak secara positif akan menghambat perkembangan karakter anak-anak dalam keluarga.

\section{Melalui Jalan Pengasuhan}

Orang tua yang penuh kasih sayang, saling pengertian, cinta, dan penghargaan. Anak tidak perlu dimanjakan karena akan mengembangkan dalam diri anak sifat mementingkan diri sendiri dan mengabaikan kebutuhan orang lain. ${ }^{29}$ Pengasuh yang terlalu menolong tidak mengembangkan karakter anak, karena hanya mengembangkan pribadi-pribadi yang manja, tidak mandiri bahkan bisa menumbuhkan sifat berpikiran sempit, tidak memilih perspektif luas sehingga tidak menyadari kebutuhan dasar atau keberadaan orang lain.

Pengasuhan harus berorientasi pada pengembangan sikap mandiri, hal-hal yang sudah bisa dan mampu dilakukan oleh anak seharusnya tidak lagi di kerjakan orang tua. Dengan cara demikian kita memberi model dan pengalaman hidup bagi anak-anak untuk mengembangkan karakternya. Orang tua perlu menciptakan lingkungan keluarga penuh kasih sayang tapi tidak terlalu memanjakan anak, mengajarka anak untuk mandiri sejak awal merupakan salah satu landasan bagi pengembangan karakter anak.

\footnotetext{
${ }^{29}$ Ibid. h. 49.
} 


\section{Melalui Jalan Pengetahuan}

Dirumah perlu diberi ruang bagi anak untuk mengembangkan wawasan ilmu pengetahuannya. ${ }^{30}$ Mungkin dialog dengan orang tua yang sudah memiliki pengetahuan yang lebih luas dapat memperluas pengetahuan anak sehingga membantu usaha eksploitatif dan pencariannya terhadap kekayaan ilmu pengetahuan itu sendiri.

\section{Melalui Jalan Perubahan Pribadi (kreatifitas)}

Untuk mengembangkan kreatifitas anak membutuhkan waktu bagi dirinya sendiri untuk dapat berimajinasi dan kemudian menciptakan sesuatu sesuai hasil imajinasinya. ${ }^{31}$ Banyaknya larangan mungkin akan menghambat ruang kreatifitas anak. Untuk itu orang tua tidak harus banyak melarang tetapi harus banyak mengarahkan anak pada kegiatan positif dan berdialog dengan anak-anak, sehingga mereka dapat menggunakan kebebasan kreatifitasnya dengan tetap dalam pengawasan orang tua.

\section{Melalui Jalan Persaudaraan}

Hal inilah yang paling dapat dilatih dalam keluarga, melalui sikap saling terbuka semua anggota keluarga dengan berdialog satu sama lain. Setiap kesulitan atau konflik yang timbul dalam keluarga dipecahkan bersama dengan saling menghargai satu sama lain. ${ }^{32}$ Untuk dapat berdialog diandalkan kemampuan untuk saling mendengarkan dan kemampuan menerima pendapat yang berbeda. Pengalaman seperti ini jika dipupuk dalam lingkungan keluarga maka sangat baik untuk peningkatan karakter anak.

\footnotetext{
${ }^{30}$ Ibid. h. 50.

${ }^{31}$ Ibid.

${ }^{32}$ Ibid., h. 51.
} 


\section{Melalui Jalan Kepemimpinan yang Penuh Pengabdian}

Orang tua adalah model seorang pemimpin yang akan dialami oleh anak-anak didalam keluarga. Pemimpin yang efektif seorang yang bersikap ramah, mampu memahami perasaan yang dipimpin dan mampu berhubungan dengan semua anggota keluarga. ${ }^{33}$ Disini orang tua dapat menjadi model bagi anak-anak untuk melayani, rela berkorban, dan mengutamakan kepentingan bersama dari pada kepentingan diri sendiri. Karena yang memandu setiap perilaku adalah apa yang bernilai dan bermakna bagi semua.

Singkatnya, tempat pertama untuk pembinaan dan menumbuhkan karakter pada anak adalah keluarga. Anak-anak yang dibesarkan dalam lingkungan keluarga yang berkarakter akan menjadi pribadi-pribadi yang berkarakter pula.

\footnotetext{
${ }^{33}$ Ibid., h. 52.
} 


\section{DAFTAR PUSTAKA}

Abdullah, Mas Udik, Ledakkan IESQ dengan Langkah Taqwa dan Tawakal, Cet. I, Jakarta: Zikrul Hakim, 2005.

Abdullah, Nashih Ulwan, Pedoman Pendidikan Anak dalam Islam, Jakarta: Asy-yfa', 1993.

Adhim, F.M, Hubungan Antara Orientasi Religius Dan Perilaku Menolong Altruistik Pada Remaja Muslim. Skripsi, t.p., Yogyakarta: Fakultas Psikologi UGM, 2001.

Atkinson, et.al., Pengantar Psikologi, Ed. IIX, Jakarta: Penerbit Erlangga, 1997.

Andrianto, S, Hubungan kematangan Beragama dengan Intensi Prososial pada Mahasiswa Fakulta Psikologi Universitas Islam Indonesia . Skripsi, t.p., Yogyakarta: Fakultas Psikologi UII, 1999.

Agustian, Ary Ginanjar. Rahasia Sukses Membangun Emosi dan Spiritual Berdasarkan Enam Rukun Iman dan Lima Rukun Islam. Jakarta : Arga Wijaya Persada, 2001.

, Rahasia Sukses Membangun ESQ Power. Jakarta: Arga Wijaya Persada, 2003.

, Rahasia Sukses Membangun Kecerdasan Emosi dan Spiritual ESQ, Cet. I; Jakarta: Penerbit Arga, 2001.

Ahmadi, Abu, Ilmu Pendidikan. Al-Maraghi, Ahmad Musthafa. Terjemahan Tafsir Al-Maraghi (21). Semarang : CV. Toha Putra, 1987.

Al-Syaibani, Muhammad Omar Al-Taumy. Falsafah Pendidikan Islam. Jakarta: Bulan Bintang, t.th.

An Nida' (Majalah Ilmu Pengetahuan Agama Islam), Pendidikan, Bahasa dan Kepemudaan. Pekanbaru: Pusat Penelitian IAIN Sultan Syarif Qasim, 1997.

Chaplin, Kamus Lengkap Psikologi. Jakarta: Rajawali, 1989.

Darajat, Zakiah, Ilmu Jiwa Agama. Jakarta: Bulan Bintang, 1976. , Kesehatan Mental. Jakarta: PT. Toko Gunung Agung, 2001. 